\title{
Influence of different nitrate and iron availabilities on phosphoenolpiruvate carboxilase and malate dehydrogenase in roots of maize (Zea mays L.) plants
}

\author{
M. A. Russo*, S. Giannetto, A. Belligno \\ Department of Agrochemistry, University of Catania, via Santa Sofia 98, Italy
}

\begin{abstract}
The effect of the different nitrate $\left(\mathrm{NO}_{3}\right)$ availability on some enzymatic activities has been evaluated in iron $(\mathrm{Fe})$ deficient and iron sufficient maize plants (Zea mays L.) in order to evaluate the induction of $\mathrm{Fe}$ sensitiveness to enzymatic activities. The apoplast reactions may be altered due to the different nitrate availability. Two experimental tests were done on maize plants grown in nutrient solution with different $\mathrm{NO}_{3}$ availability and with Fe-sufficiency and Fedeficiency. Phosphoenolpiruvate carboxilase (PEPcase) and malate dehydrogenase activities, for the reaction determined in citosol, by $\mathrm{NO}_{3}$ uptake, showed different responses according to $\mathrm{Fe}$ availability. The different nitrate availability caused a difference in the acid content. These results justifies the higher energy demand to activate membrane carriers under stress conditions for the reduced nitrate availability.
\end{abstract}

Keywords: Zea mays, iron availability, phosphoenolpiruvate carboxilase, malate dehydrogenase.

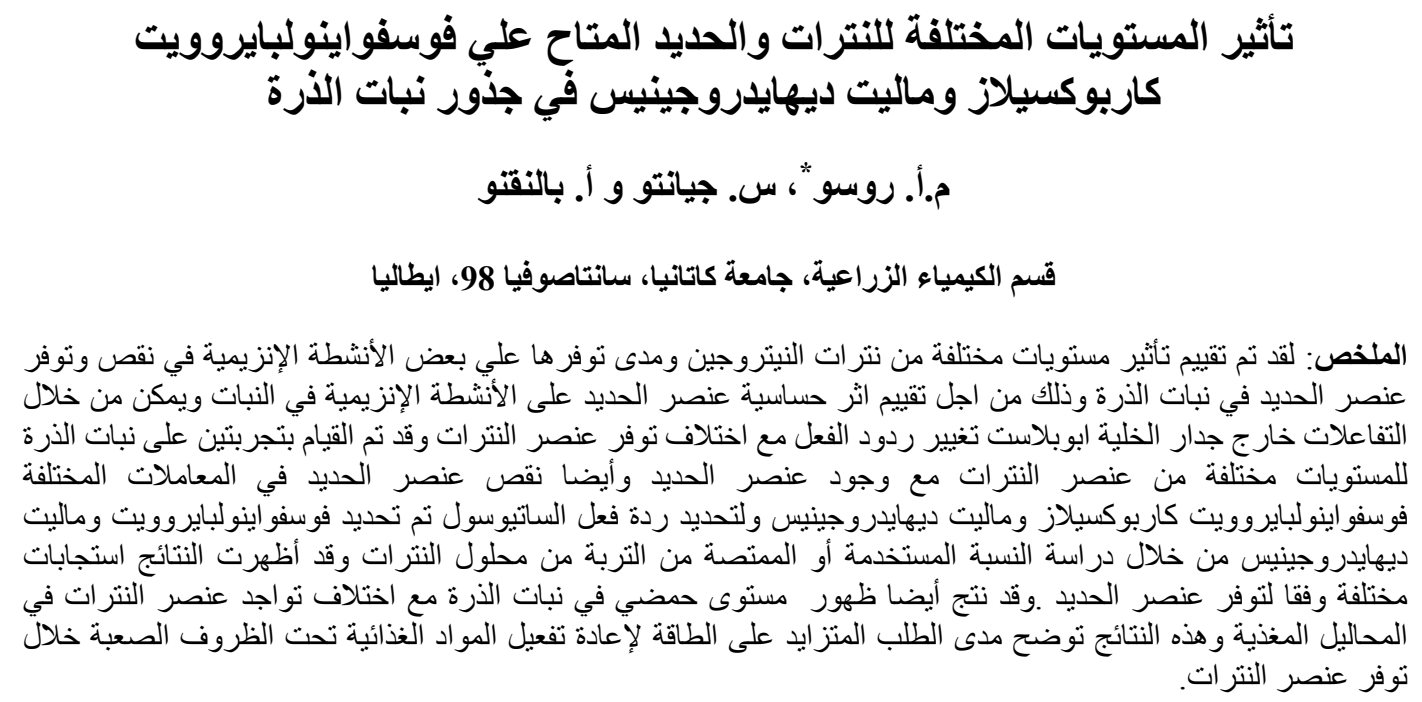

\section{Introduction}

Though iron is one of the most abundant elements of the lithosphere (5\%), its availability in the soil is linked with a series of balances between ions and free oxides (Cesco et al., 2001), depending on redox potential and $\mathrm{pH}$ (Thoiron et al., 1997). This availability is affected by the tendency to hydrolysis of ferric salts, the greater mobility of $\mathrm{Fe}^{2+}$ compounds and the chelating action of organic substance. The reduced iron availability in calcareous soils due to high value of $\mathrm{pH}$, interferes with plants development. Due to its implications in redox processes, its deficiency affects the biochemical properties of the nutrients, above all of nitrogen. Nitrate $\left(\mathrm{NO}_{3}{ }^{-}\right)$assimilation, done by plants by means of a co-transport mechanism through symport in the ratio $2 \mathrm{H}^{+} / 1 \mathrm{NO}_{3}^{-}$, causes $\mathrm{pH}$ changes both in the cytosol and apoplast (Aslam and Travis, 2001; Espen, 2001). Under iron deficiency, maize plants follow 'Strategy II' which is above all characterised by the release, independent from rhyzosphere $\mathrm{pH}$, of phytosiderophores, non proteic nitrogen 
chelated compounds with molecular weight of about $320 \mathrm{Da}$. Studies done on maize suggest that nitrate use needs $\mathrm{H}^{+}$ATPase activation and is strictly connected to enzymatic systems, linked with $\mathrm{e}^{-}$ transport and therefore dependent on containing iron compounds (Thoiron et al., 1997). Nitrate uptaking systems are, therefore, induced by anion external concentration that influences $\mathrm{H}^{+}$-ATPase activity and nitrate reductase. The latter is directly proportional to the nitrate and iron availabilities. Also nitrate internal translocation is linked with such enzymatic systems. Plasma membrane Fe(III)chelate reductase activity seems to be more linked with $\mathrm{pH}$ variations, rather than with the micro-nutrient availability.

In maize plants the variation of $\mathrm{pH}$ of the soil solution, caused by nitrate uptake, influenced constitutive $\mathrm{Fe}(\mathrm{III})$ chelate reductase and plasma membrane $\mathrm{H}^{+}$ATPases, as well as nitrate reductase and roots and leaves internal nitrate contents.

In order to uptake iron, maize plants, release phytosiderophores (Takagi et al., 1984) and activate on the plasma membrane of root cells a high affinity uptaking system for $\mathrm{pH}$ dependent $\mathrm{Fe}^{3+}$ phytosiderophore (Römheld, 1987).

Since iron deficiency induced in maize plants a $\mathrm{H}^{+}$release (Davies, 1986; Landsberg, 1981), the present work was carried out to point out in iron deficient and sufficient maize plants, the influence of the different nitrate availability on sugar and organic acid contents and on phosphoenolpiruvate carboxilase and malate dehydrogenase activities, enzymes that regulate $\mathrm{pH}$-stat mechanisms.

\section{Material and Methods}

Maize seeds (Zea mays L., Commercial hybrid Cecilia, Pioneer S.p.A.), soaked in distilled water for 24 hours, were put on a metallic net rested on a plastic pot containing $5 \mathrm{~L}$ of $0.5 \mathrm{mM}$ $\mathrm{CaSO}_{4}$. Seeds were germinated in the dark, till cotyledons emission at $95 \%$ relative humidity $(\mathrm{RH})$ and $27^{\circ} \mathrm{C}$ temperature.
After four days, 10 groups of three plantlets each, were transferred in a growth chamber under controlled conditions $(16 / 8$ photoperiod, $20^{\circ} \mathrm{C}$ temperature and 60 $70 \% \mathrm{RH}$ ) and grown in Hoagland nutrient solution.

In order to develop the experiment, four factors were considered: two $\mathrm{NO}_{3}{ }^{-}$ concentrations and two iron concentrations, with 3 replications each.

\section{Experiment $1\left(\mathbf{N S}_{\mathbf{1}}\right)$}

$4.0 \mathrm{mM} \mathrm{NO}_{3}^{-}\left(\mathrm{NS}_{1}\right)$

a) Fe-sufficient $(+\mathrm{Fe})$, added with 80 $\mu \mathrm{M}$ Fe(III)-EDTA.

b) $\quad$ Fe-deficient $(-\mathrm{Fe})$, added with 0.1 $\mu \mathrm{M}$ Fe(III)-EDTA.

\section{Experiment 2 ( $\left.\mathbf{N S}_{2}\right)$}

$0.4 \mathrm{mM} \mathrm{NO}_{3}^{-}\left(\mathrm{NS}_{2}\right)$

c) Fe-sufficient $(+\mathrm{Fe})$, added with 80 $\mu \mathrm{M}$ Fe(III)-EDTA.

d) Fe-deficient (-Fe), added with 0.1 $\mu \mathrm{M}$ Fe(III)-EDTA.

Roots were taken from plantlets collected at the $5^{\text {th }}$ day from transfer in NS at $6,12,24,48$ and 72 hours of growth. Phosphoenolpiruvate carboxilase and malate dehydrogenase activities were determined according to Singal and Sing, 1986; Ritambhare, 2000 respectively. Furthermore, the content of organic acids (citric, malic, oxalacetic and succinic acids) and sugars (glucose, fructose and saccarose) were determined by means of gas-chromatographic apparatus (Gas Chromatograph 8310 Series, Perkin Elmer) according to Sweeley et al. (1963). The conditions were: programmed oven temp 1 $130^{\circ} \mathrm{C}$, iso time 15.0 ramp rate 16.0 , oven temp $2260^{\circ} \mathrm{C}$, iso time 27.0 , ramp rate 2 6.0 , oven temp $3280^{\circ} \mathrm{C}$, iso time 35.0 , ramp rate 30.0 , press psig 18.0, fid sens high, fid zero on, inj temp $250^{\circ} \mathrm{C}$, det temp $300^{\circ} \mathrm{C}$, relay 1 on, relay 2 off.

All the data obtained from all the analyses are the means of 3 independent experiments \pm standard deviation. 


\section{Results and Discussion}

\section{Experiment 1 ( $\left.\mathrm{NS}_{1}\right)$}

The phosphoenolpiruvate carboxilase activity shows a decreasing trend during the 72 hours period, with similar values between $(+\mathrm{Fe})$ and $(-\mathrm{Fe})$ theses till the $24^{\text {th }}$ hour. At the $48^{\text {th }}$ hour, roots of $(+\mathrm{Fe})$ plants show a decreasing activity of $41.18 \%$, reaching a significantly smaller value than $(-\mathrm{Fe})$ (Figure 1). In $(+\mathrm{Fe})$ theses the recorded decrease of enzymatic activity at the $24^{\text {th }}$ hour agrees with the $\mathrm{pH}$ increase of the nutrient solution, from 6 to 7.6 that indicates a temporary acidification of the cytoplasm, due to the activation of the nitrate uptaking system.

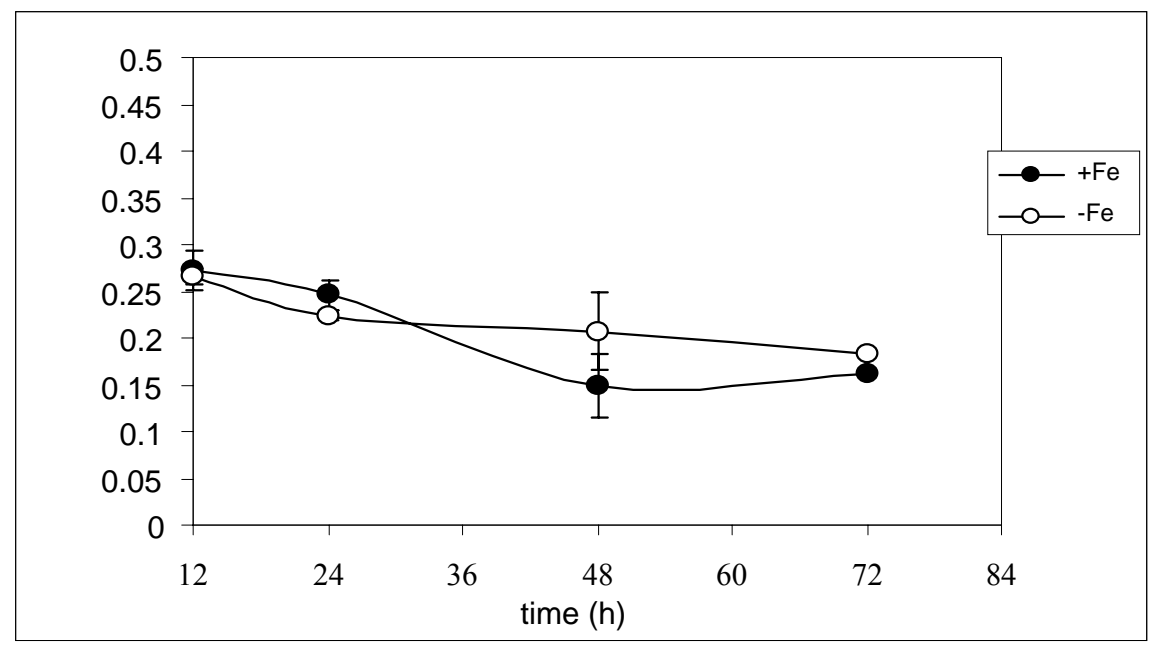

Figure 1. Phosphoenolpiruvate carboxilase (PEPcase) activity (U/mg prot.) in maize plants roots (Zea mays L.) grown in nutrient solution with $4.0 \mathrm{mM} \mathrm{NO}_{3}^{-}$, added with $80 \mu \mathrm{M}(+\mathrm{Fe})$ or $0.1 \mu \mathrm{M}$ (-Fe) Fe-EDTA.

Malate dehydrogenase activity (Figure 2), higher from the $12^{\text {th }}$ hour to the $48^{\text {th }}$ hour in $(-\mathrm{Fe})$ plants, shows a similar trend in the two theses $(+\mathrm{Fe}$ and $-\mathrm{Fe})$ with the higher value at the $6^{\text {th }}$ hour for $(+\mathrm{Fe})$ thesis and at the $12^{\text {th }}$ hour for $(-\mathrm{Fe})$ thesis.

Malic acid contents decrease in both theses till the $12^{\text {th }}$ hour, with higher values in $(+\mathrm{Fe})$. When in $(-\mathrm{Fe})$ thesis the malate dehydrogenase shows higher activity (Figure 2, 3), the malic acid contents show a decrease of the $53 \%$ and of the $66 \%$ at the $6^{\text {th }}$ and the $12^{\text {th }}$ hour respectively, when compared to the initial value. From the $12^{\text {th }}$ to the $24^{\text {th }}$ hour malic acid content, almost doubled, is higher than that of $(+\mathrm{Fe})$ thesis, maintaining till the end a higher level when compared to that recorded at the $6^{\text {th }}$ hour, but similar to $(+\mathrm{Fe})$. Succinic and citric acid contents are generally higher in (-Fe) theses after the $24^{\text {th }}$ hour (Figure 4, $5)$.

Oxalacetic acid values in (-Fe) theses are always higher and increase when compared to those of $(+\mathrm{Fe})$ theses during the whole experimental period and in agreement with the malate dehydrogenase and phosphoenolpiruvate carboxilase activities (Figure 1, 2, 6). In both theses, the measure of the malate dehydrogenase activity agrees with the variations of the malic acid contents as well as with the oxalacetic acid increase (Figure 6). 


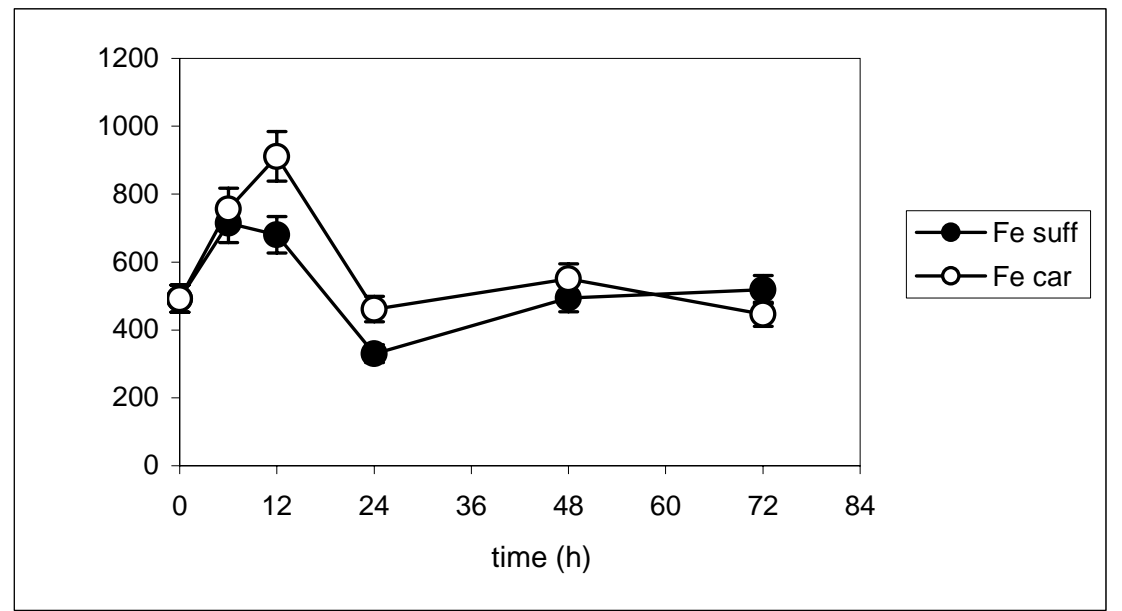

Figure 2. Malate dehydrogenase (MDH) activity (U/mg prot.) in maize plants roots (Zea mays L.) grown in nutrient solution with $4.0 \mathrm{mM} \mathrm{NO} \mathrm{N}_{3}^{-}$, added with $80 \mu \mathrm{M}(+\mathrm{Fe})$ or $0.1 \mu \mathrm{M}(-\mathrm{Fe}) \mathrm{Fe}-$ EDTA.

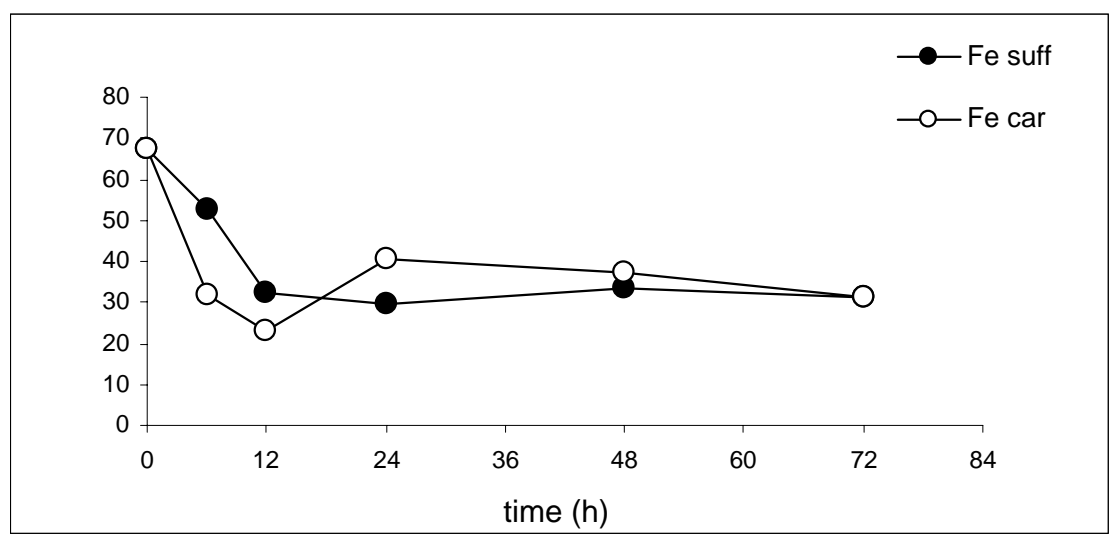

Figure 3. Malic acid content ( $\mathrm{mg} 100 \mathrm{~g}^{-1}$ f.w.) in roots of maize plants (Zea mays L.) grown in nutrient solution with $4.0 \mathrm{mM}\left(\mathrm{NS}_{1}\right) \mathrm{NO3}^{-}$, added with $80 \mu \mathrm{M}(+\mathrm{Fe})$ or $0.1 \mu \mathrm{M}(-\mathrm{Fe})$ Fe-EDTA.

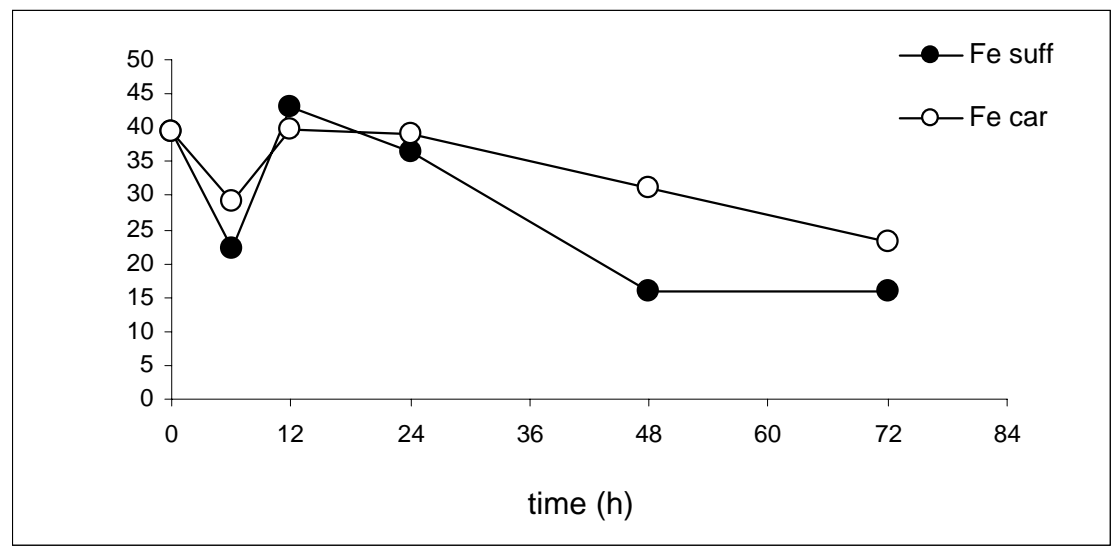

Figure 4. Succinic acid content ( $\mathrm{mg} 100 \mathrm{~g}-1 \mathrm{f} . w$.$) in roots of maize plants (Zea mays L.) grown in$ nutrient solution with $4.0 \mathrm{mM}$ (SN1) NO3-, added with $80 \mu \mathrm{M}(+\mathrm{Fe})$ or $0.1 \mu \mathrm{M}(-\mathrm{Fe})$ Fe-EDTA. 


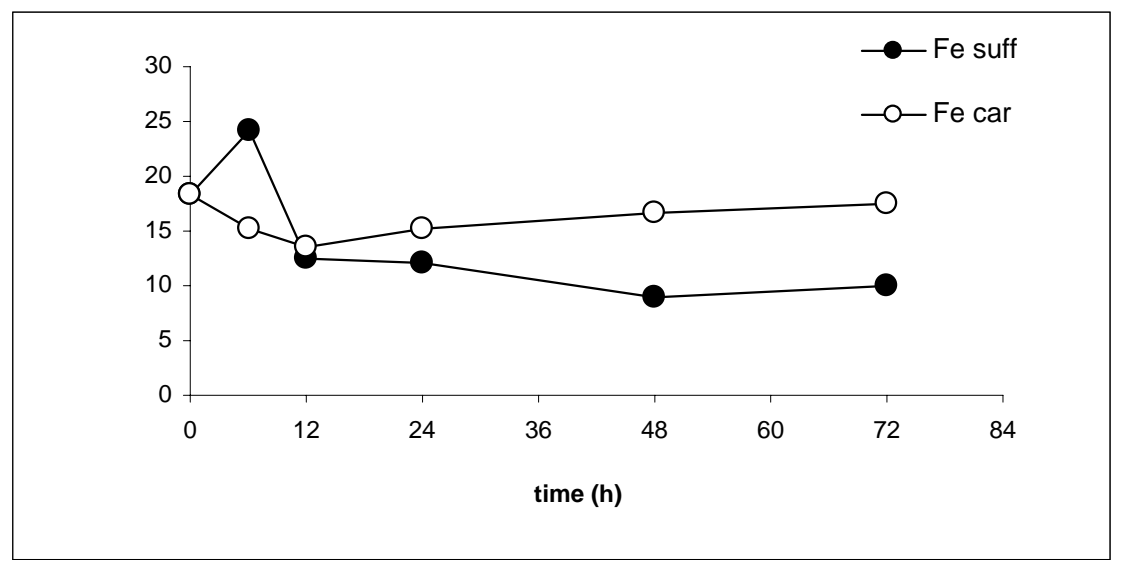

Figure 5. Citric acid content ( $\mathrm{mg} 100 \mathrm{~g}^{-1}$ f.w.)in roots of maize plants (Zea mays L.) grown in nutrient solution with $4.0 \mathrm{mM}\left(\mathrm{SN}_{1}\right) \mathrm{NO}_{3}^{-}$, added with $80 \mu \mathrm{M}(+\mathrm{Fe})$ or $0.1 \mu \mathrm{M}(-\mathrm{Fe}) \mathrm{Fe}-\mathrm{EDT}$.

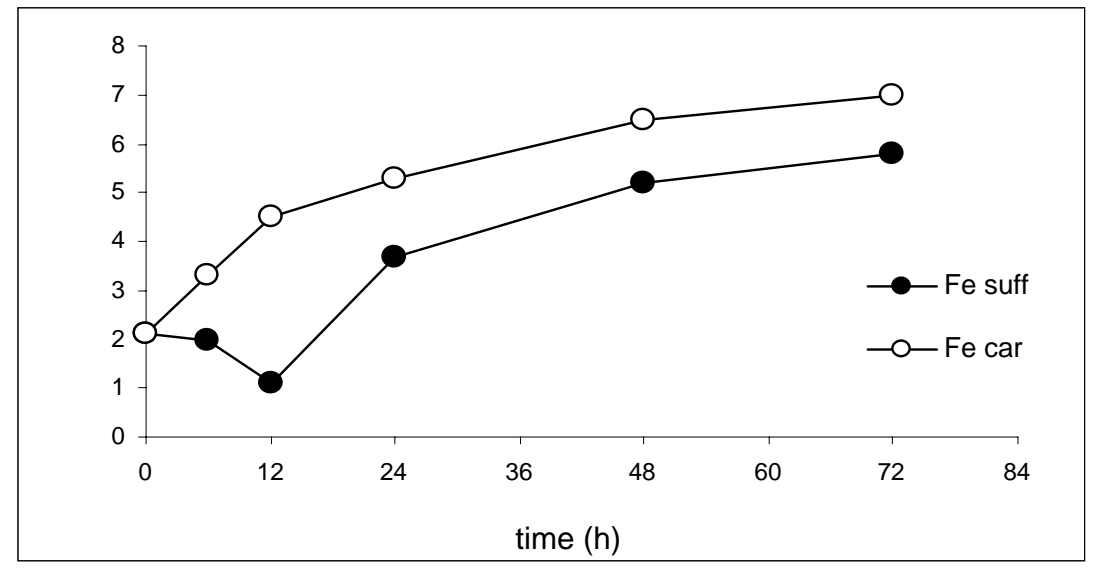

Figure 6. Oxalacetic acid content ( $\mathrm{mg} 100 \mathrm{~g}^{-1}$ f.w.) in roots of maize plants (Zea mays L.) grown in nutrient solution with $4.0 \mathrm{mM}\left(\mathrm{SN}_{1}\right) \mathrm{NO}_{3}{ }^{-}$, added with $80 \mu \mathrm{M}(+\mathrm{Fe})$ or $0.1 \mu \mathrm{M}(-\mathrm{Fe}) \mathrm{Fe}-\mathrm{EDTA}$.

Malate dehydrogenase and phosphoenolpiruvate carboxilase activities of $(-\mathrm{Fe})$ theses are the response to the mechanisms that guarantee cell omeostases, connected to carboxilase ions production (Landsberg, 1986; Bienfait et al., 1989; Rabotti et al., 1995).

The increase of anions production in (-Fe) theses justifies the temporary alcalinization of cytoplasma and PEP carboxilase activation. Furthermore, it links the enzymatic activity to the cell mechanism of stat pH (Landsberg, 1986; Miller et al., 1990; Abadìa et al., 2002).

In iron deficient roots, the malic acid decrease and oxalacetic acid increase might suggest that their utilization is involved, in particular as a mitocondrial organic component, in the production of energy (Abadìa et al., 2002; Andaluz et al., 2001; Lòpez-Millàn et al., 2000) for nutrients assimilation. Furthermore, under iron deficiency the higher production of these acids can be due to the necessity to implement their contents to induce the synthesis of molecules involved in $\mathrm{Fe}$ finding, as it has already been observed in other vegetable species (Bialczyk and Lechowski, 1992).

In iron sufficient theses, citrate decrease after the $6^{\text {th }}$ hour, might be referred to its use, above all, to satisfy the 
energetic demands. On the contrary, its increases in the iron deficient theses point out its role as a starting molecule involved in the synthesis of phytosiderophores necessary to iron assimilation (Pich et al., 1994).

\section{Experiment $2\left(\mathbf{N S}_{2}\right)$}

Phosphoenolpiruvate carboxilase activity shows an increasing trend till the $48^{\text {th }}$ hour for $(-\mathrm{Fe})$ and $(+\mathrm{Fe})$ theses, pointing out significantly different values between the two theses only at the $48^{\text {th }}$ hour (Figure 7). The higher expression of this activity in $(-\mathrm{Fe})$ theses might be due to a $\mathrm{pH}$ increase in citosol as a response to the higher protons extrusion, due to $\mathrm{H}^{+}$ATPase activation and to the lower $\mathrm{pH}$ value in the growth medium that is of 4.0 and 3.9 for $(+\mathrm{Fe})$ and $(-\mathrm{Fe})$ theses, respectively.

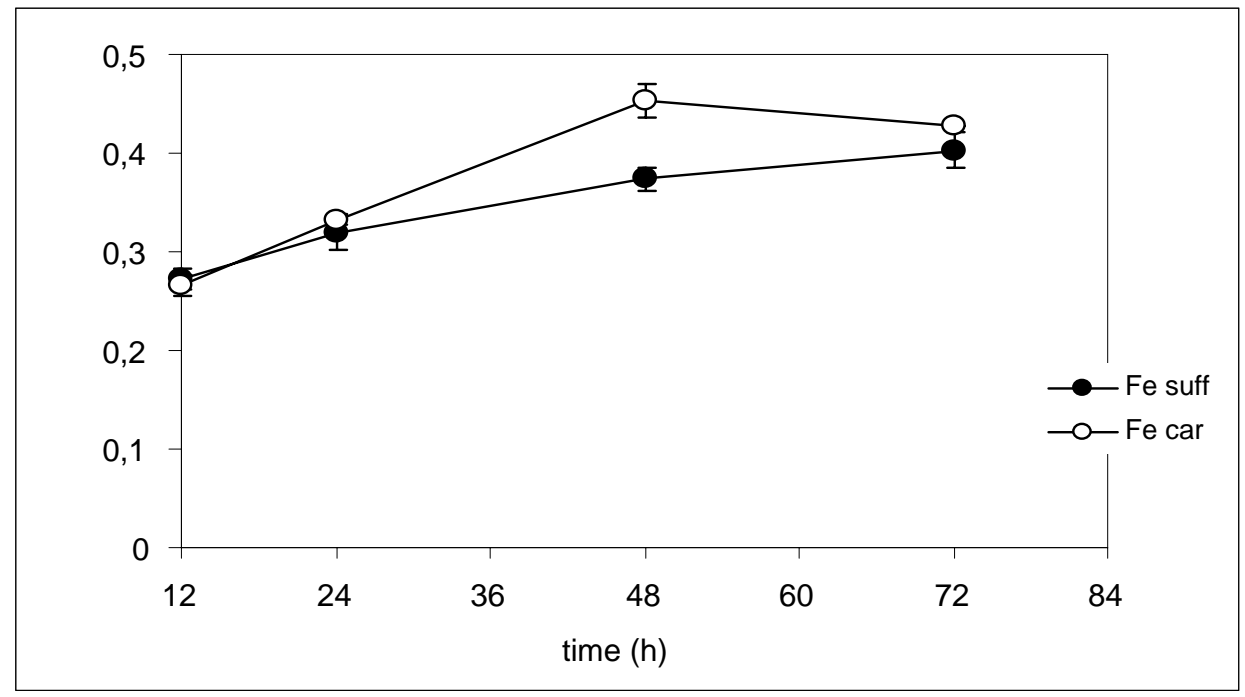

Figure 7. Phosphoenolpiruvate carboxilase (PEPcase) activity (U/mg prot.) in roots of maize plants (Zea mays L.) grown in nutrient solution with $0.4 \mathrm{mM} \mathrm{NO}_{3}^{-}$, added with $80 \mu \mathrm{M}(+\mathrm{Fe})$ or $0.1 \mu \mathrm{M}(-\mathrm{Fe})$ Fe-EDTA.

The more evident activation of PEPcase in $(-\mathrm{Fe})$ theses might be referred to the higher protons extrusion (growth medium $\mathrm{pH}=3.9$ and 4.3 at the $48^{\text {th }}$ and $72^{\text {nd }}$ hour respectively).

Malate dehydrogenase activity shows a fluctuating and similar trend independently of the theses, resulting higher till the $12^{\text {th }}$ hour in $(+\mathrm{Fe})$ thesis that shows the highest value at the $6^{\text {th }}$ hour (Figure 8). At the $48^{\text {th }}$ hour, in (-Fe) thesis appears a significantly higher value in comparison with $(+\mathrm{Fe})$ thesis with an activity increase of the $51 \%$. From the $48^{\text {th }}$ to the $72^{\text {nd }}$ hour the value is that recorded at the $24^{\text {th }}$ hour (Figure 8).

Oxalacetic acid contents were not detectable in both theses, while those of malic acid showed a decrease till the $24^{\text {th }}$ hour, with lower values always for $(-\mathrm{Fe})$ theses (Figure 9).

Succinic acid contents, steady in (-Fe) theses, increase at the $24^{\text {th }}$ hour for $(+\mathrm{Fe})$ theses. The significant decrease recorded at the $48^{\text {th }}$ hour in $(+\mathrm{Fe})$ thesis leads the acid levels to lower values than those of (-Fe) (Figure 10). At the $72^{\text {nd }}$ hour, $(+\mathrm{Fe})$ theses show similar values to those of $(-\mathrm{Fe})$.

Citric acid content shows always lower values in (-Fe) theses, decreasing till the $24^{\text {th }}$ hour with significant differences when compared to $(+\mathrm{Fe})$ at the $48^{\text {th }}$ and the $72^{\text {nd }}$ hour. Both theses have similar trend and show the higher value at the $48^{\text {th }}$ hour (Figure 11). 


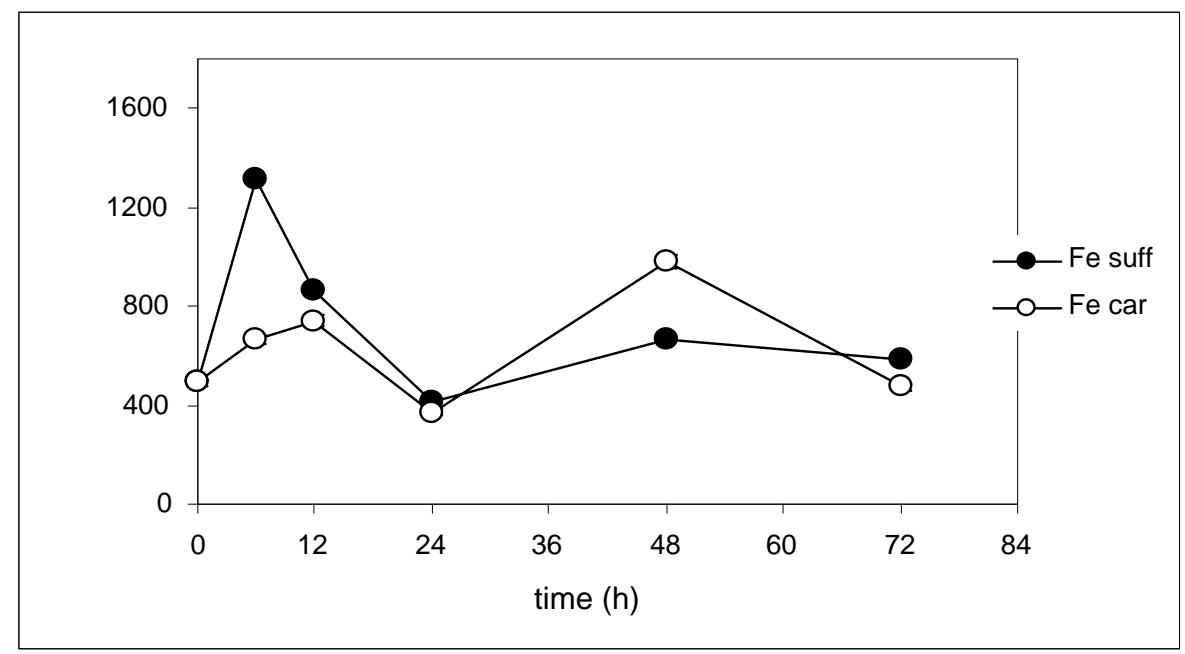

Figure 8. Malate dehydrogenase (MDH) activity (U/mg prot.) in roots of maize plants (Zea mays L.) grown in nutrient solution with $0.4 \mathrm{mM} \mathrm{NO}_{3}{ }^{-}$, added with $80 \mu \mathrm{M}(+\mathrm{Fe})$ or $0.1 \mu \mathrm{M}(-\mathrm{Fe}) \mathrm{Fe}-$ FDTA.

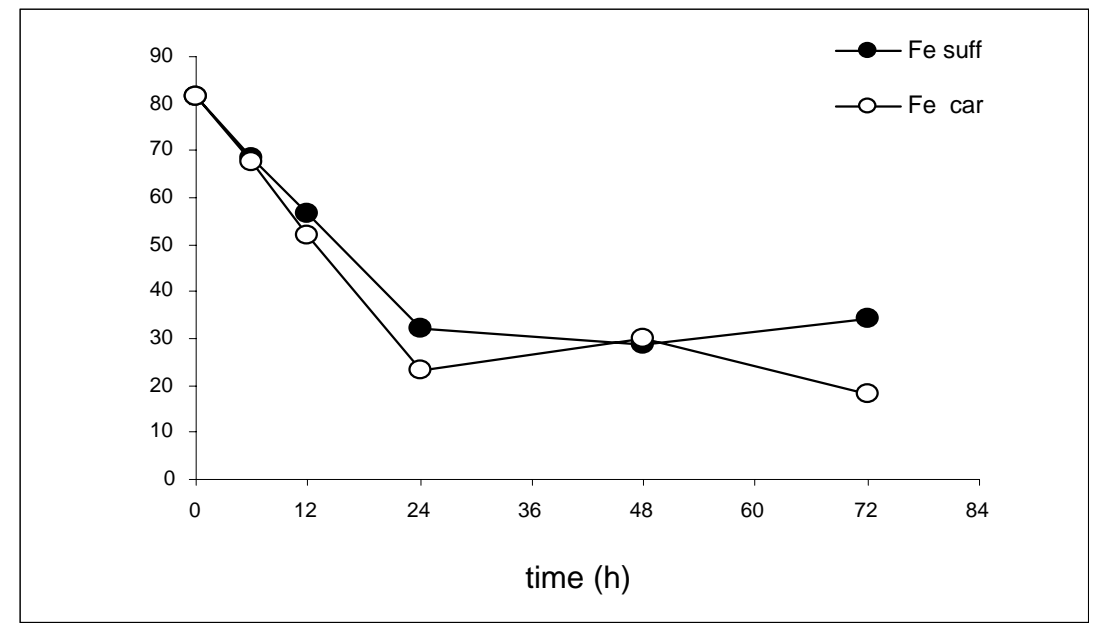

Figure 9. Malic acid content (mg $100 \mathrm{~g}^{-1}$ f.w.) in roots of maize plants (Zea mays L.) grown in nutrient solution with $0.4 \mathrm{mM}$ (NS2) NO3-, added with $80 \mu \mathrm{M}(+\mathrm{Fe})$ or $0.1 \mu \mathrm{M}(-\mathrm{Fe})$ Fe-EDTA.

During the whole examined period, $(+\mathrm{Fe})$ thesis shows in $\mathrm{NS}_{1}$ a decreasing trend of total acid contents. In $(-\mathrm{Fe})$ theses the acid levels (Figure 12), appear to be lower during the first 12 hours when compared to those of $(+\mathrm{Fe})$ theses. The acid contents show at the $24^{\text {th }}$ hour a $25 \%$ increase and the values are higher than those of $(+\mathrm{Fe})$ theses till the $72^{\text {nd }}$ hour, with significant differences of the values (Figure 12).

In $\mathrm{NS}_{2}$ the two theses have the same trend, however the values are always higher in $(+\mathrm{Fe})$ (Figure 13). 


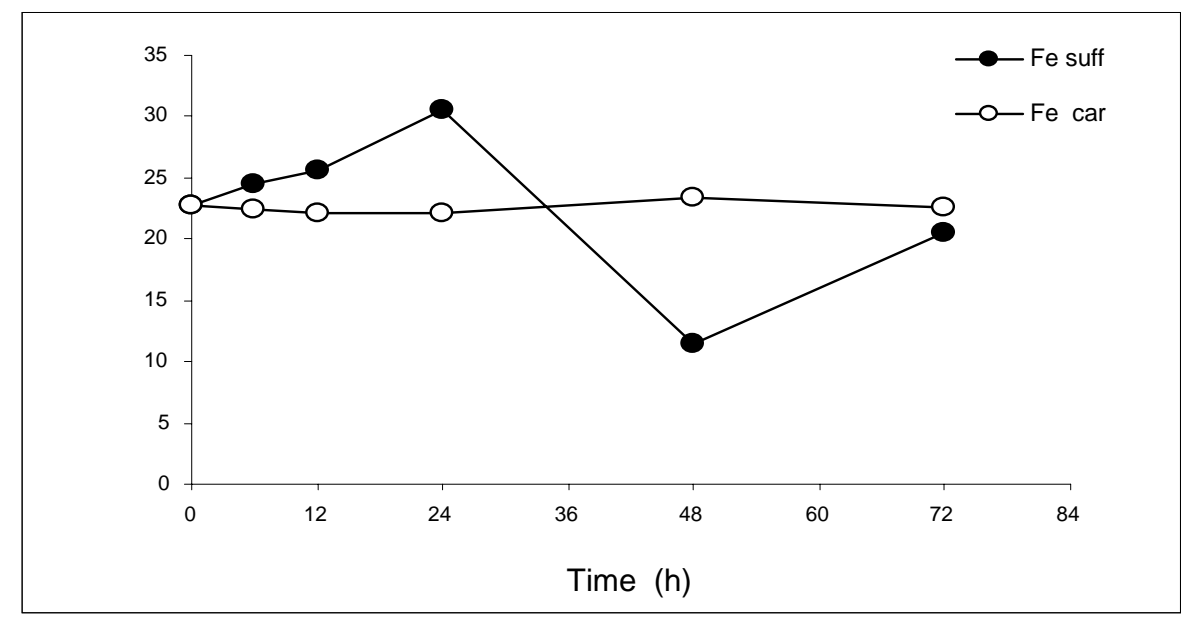

Figure 10. Succinic acid content (mg $100 \mathrm{~g}^{-1}$ f.w.) in roots of maize plants (Zea mays L.) grown in nutrient solution with $0.4 \mathrm{mM}$ (NS2) NO3-, added with $80 \mu \mathrm{M}(+\mathrm{Fe})$ or $0.1 \mu \mathrm{M}(-\mathrm{Fe})$ Fe-EDTA.

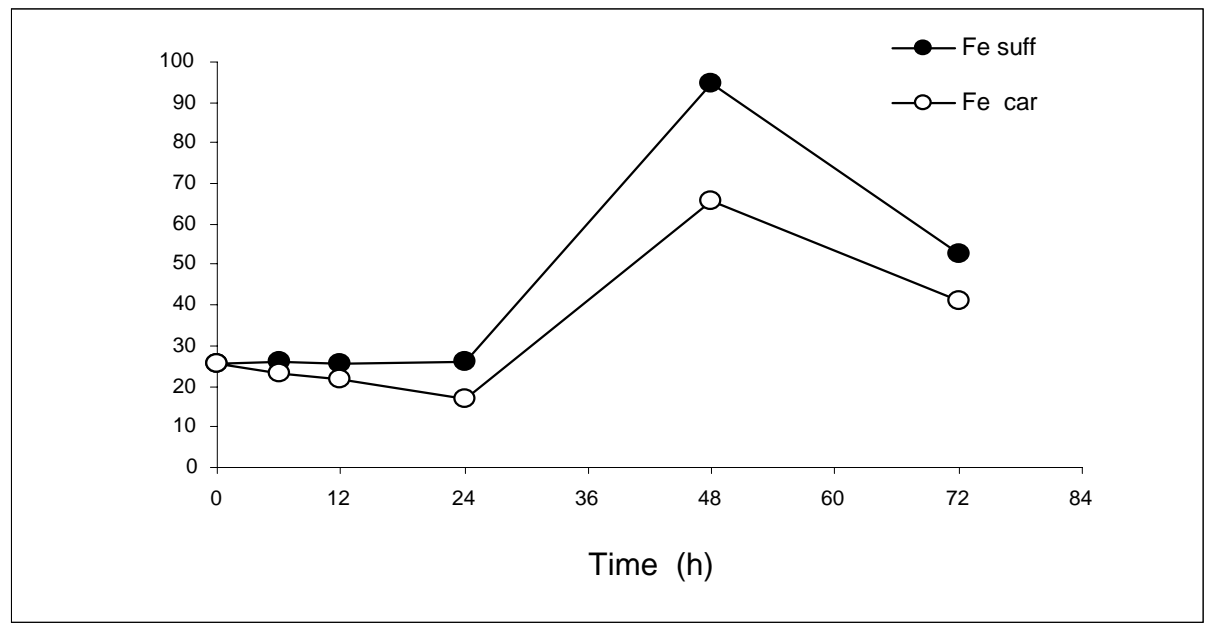

Figure 11. Citric acid content ( $\mathrm{mg} 100 \mathrm{~g}^{-1}$ f.w.) in roots of maize plants (Zea mays L.) grown in nutrient solution with $0.4 \mathrm{mM}\left(\mathrm{NS}_{2}\right) \mathrm{NO}_{3}^{-}$, added with $80 \mu \mathrm{M}(+\mathrm{Fe})$ or $0.1 \mu \mathrm{M}(-\mathrm{Fe})$ Fe-EDTA.

Landsberg (1986) observed in the roots of iron deficient plants an increase of organic acids as a response to balance a possible organic acid extrusion by the roots. We too have found in $\mathrm{NS}_{1}$ an increase, particularly evident for citric acid, that might be connected to the strategy done by maize for iron uptake, and therefore to the needs to produce phytosiderophores in the Fe deficiency. In this condition citric acid plays a role of a chelating agent for $\mathrm{Fe}^{2+}$ (Tiffin, 1966; Pich et al., 1995) but also to move the cation towards vegetative apexes (Bienfait, 1996).
In $\mathrm{NS}_{2}$ (Figure 13) the values of total organic acid show an initial decrease in both theses, with particular evidence in (-Fe) theses. This specific picture might depend on the higher demand of energy necessary to activate the transport through membranes where a doubled activity of the plasma membrane $\mathrm{H}^{+}$-ATPase plasma membrane was observed when compared to theses with $4.0 \mathrm{mM} \mathrm{NO}_{3}^{-}$, showing moreover higher values for (-Fe) plants (date not shown). The higher respiratory activity linked to ATP request necessary to implement plasma membrane $\mathrm{H}^{+}$-ATPase 
pump activity involved in nitrate and iron transport (Miller et al., 1990), justifies the non detectability of oxalacetic acid in both theses, where $\mathrm{NO}_{3}{ }^{-}$deficiency creates stress conditions similar for both $(+\mathrm{Fe})$ and (-Fe) theses.

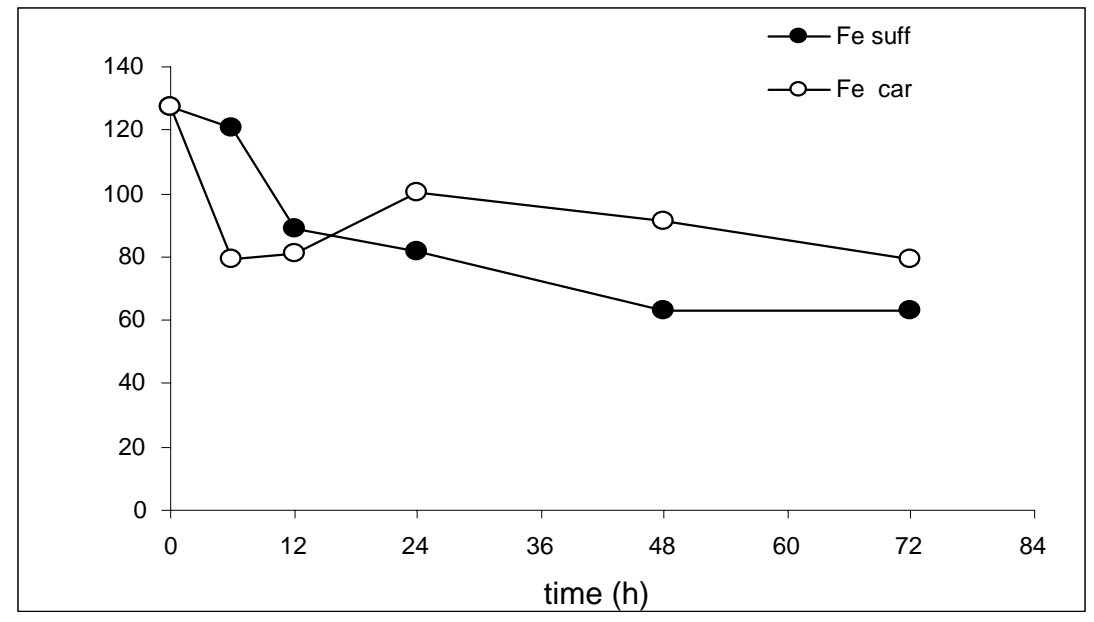

Figure 12. Total acid contents $(\mathrm{mg} / 100 \mathrm{~g}$ f. w.) in roots of maize plants (Zea mays $\mathrm{L}$.) grown in nutrient solution with $4.0 \mathrm{mM}\left(\mathrm{NS}_{1}\right) \mathrm{NO}_{3}^{-}$, added with $80 \mu \mathrm{M}(+\mathrm{Fe})$ or $0.1 \mu \mathrm{M}(-\mathrm{Fe})$ Fe-EDTA.

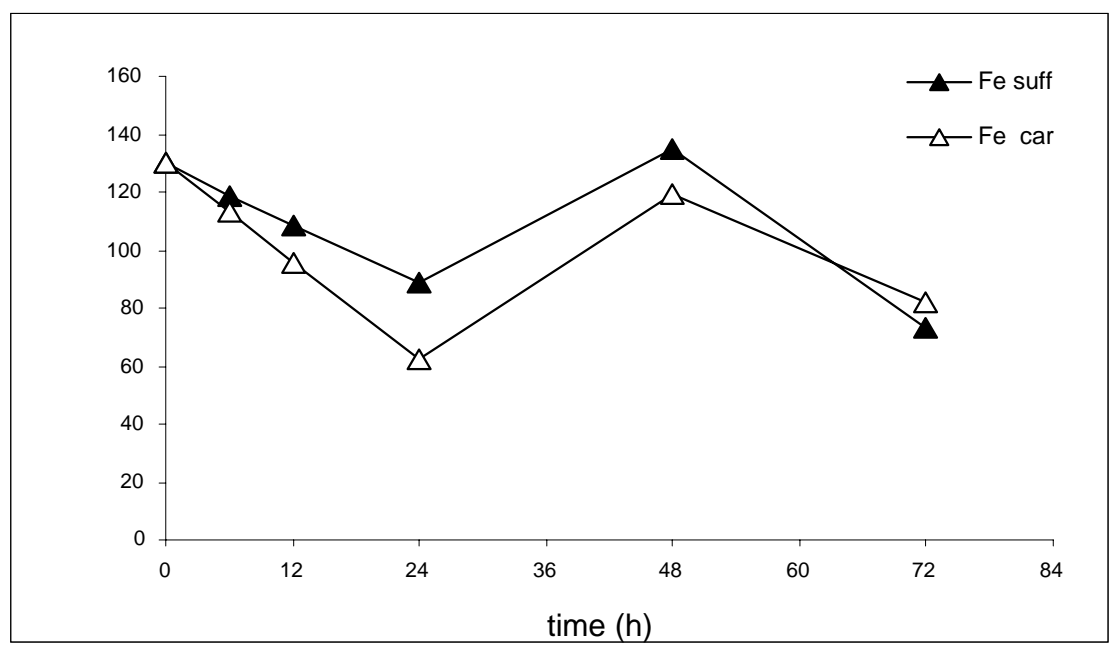

Figure 13. Total acid content ( $\mathrm{mg} / 100 \mathrm{~g}$ f.w.) in roots of maize plants (Zea mays $\mathrm{L}$.) grown in nutrient solution with $0.4 \mathrm{mM}\left(\mathrm{NS}_{2}\right) \mathrm{NO}_{3}^{-}$, added with $80 \mu \mathrm{M}(+\mathrm{Fe})$ or $0.1 \mu \mathrm{M}(-\mathrm{Fe}) \mathrm{Fe}-\mathrm{EDT}$.

In $\mathrm{NS}_{1}$, glucose content in $(-\mathrm{Fe})$ plants shows significant decrease from the $6^{\text {th }}$ to the $72^{\text {nd }}$ hour, with higher values when compared to $(+\mathrm{Fe})$ till the $48^{\text {th }}$ hour (Fig. 14). In $(+\mathrm{Fe})$ plants, after the decrease recorded till the $24^{\text {th }}$ hour, the glucose contents of the following stages shows significant increases till the $72^{\text {nd }}$ hour, with higher values when compared to that recorded for (-Fe) plants. Fructose and saccarose contents show very lower values than those of glucose without significant differences between $(+\mathrm{Fe})$ and $(-\mathrm{Fe})$ theses. 


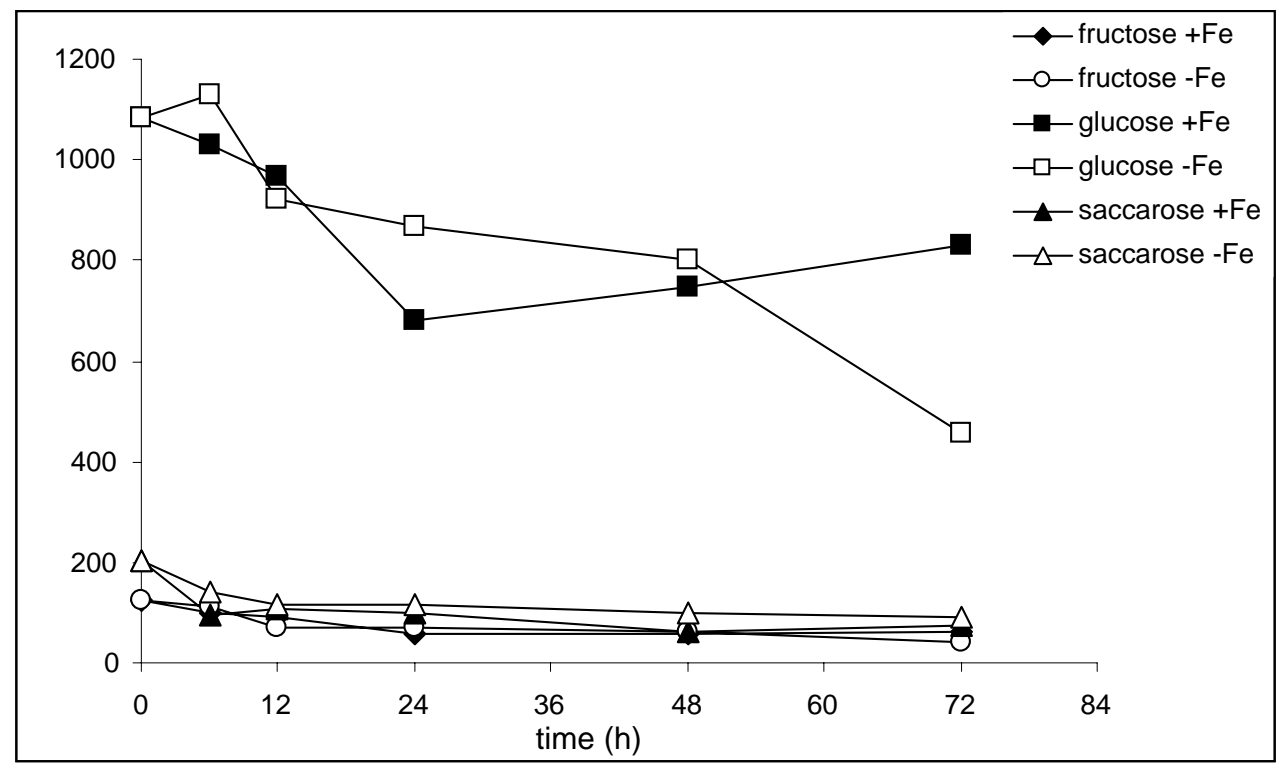

Figure 14. Fructose, glucose and saccarose $\left(\mathrm{mg} 100 \mathrm{~g}^{-1}\right.$ f.w.) contents in the roots of maize plants (Zea mays $\mathrm{L}$.) grown in nutrient solution with $4.0 \mathrm{mM} \mathrm{NO}_{3}^{-}\left(\mathrm{NS}_{1}\right)$, added with $80 \mu \mathrm{M}(+\mathrm{Fe})$ or 0.1 $\mu \mathrm{M}$ (-Fe) Fe-EDTA.

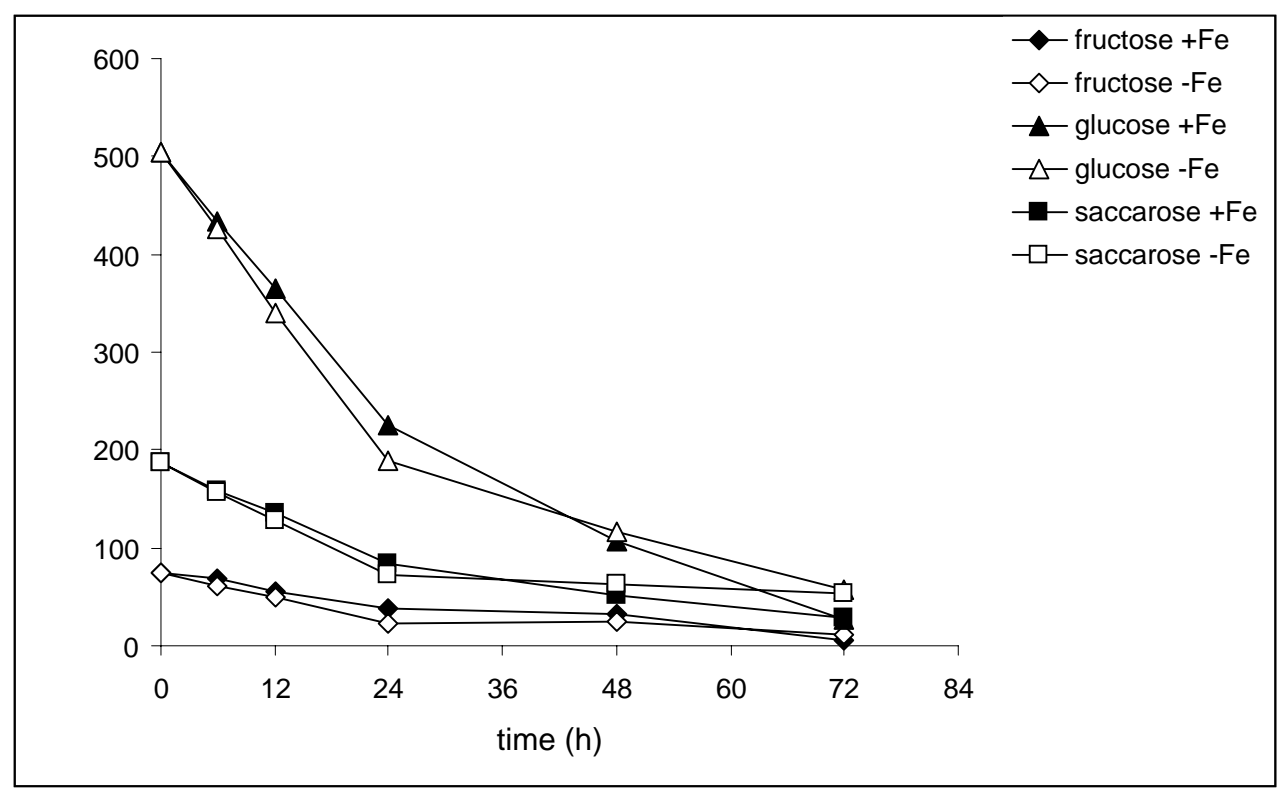

Figure 15. Fructose, glucose and saccarose contents $\left(\mathrm{mg}^{100 \mathrm{~g}^{-1}} \mathrm{f}\right.$.w. $)$ in the roots of maize plants (Zea mays L.) grown in nutrient solution with $0.4 \mathrm{mM} \mathrm{NO3-}(\mathrm{NS2})$, added with $80 \mu \mathrm{M}(+\mathrm{Fe})$ or $0.1 \mu \mathrm{M}(-\mathrm{Fe})$ Fe-EDTA.

In $\mathrm{NS}_{2}$ it is possible to observe decreasing values for glucose, saccarose and fructose, in both theses and with lower values in $(-\mathrm{Fe})$ theses when compared to those of $(+\mathrm{Fe})$ (Figure 15, 16).

The higher values of glucose confirm the use of this monosaccaride in the roots as a source of energy above all for $(-\mathrm{Fe})$ theses.

The variations of sugar contents in both experiments agree with those observed for the organic acids, pointing out the use of this compound in relation to the different energy demand in order to 
allow the nutrient transport through plasma membrane. They also promote secundary metabolic cycles necessary to effectuate iron acquisition mechanism.

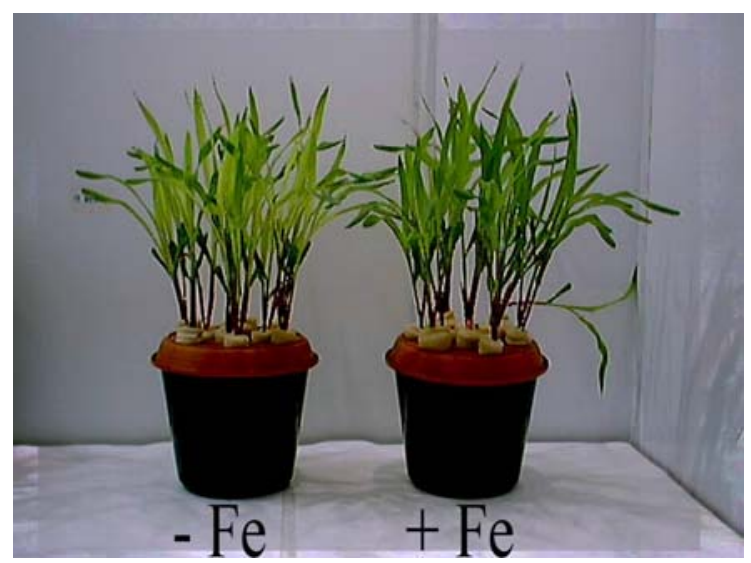

Figure 16. Plants with different availability of iron.

\section{Conclusion}

The induction of $\mathrm{pH}$ sensitive enzymatic activities is influenced by the variation of the apoplast reaction determined by the different nitrate availability. The different response of the two activities shows to be induced by the reaction caused in the citosol by $\mathrm{NO}_{3}{ }^{-}$ uptake and with different activities according to Fe availability. In both theses the enzymatic activity, though it has during time the same trend, points out, however, a shifting of the higher activity peak, showing that iron deficiency conditions, interfering with $\mathrm{e}^{-}$transport, determine a slowing down of the enzyme induction independently of the nitrate availability.

The different nitrate availability implies also a different impact on acid contents. In fact, $\mathrm{Fe}$ deficiency in $\mathrm{NS}_{1}$ increases citrate content, precursor of molecule for phytosiderophores production. On the contrary, low nitrate availabilities determine a decrease in acid contents, mostly in $(-\mathrm{Fe})$ theses, because of the higher energy demand necessary to activate membrane carriers under stress conditions.

\section{References}

Abadìa, J., A. Lòpez-Millàn, A. Rombolà and A. Abadìa. 2002. Organic acids and Fe deficiency: A review. Plant Soil 241:75-86.

Andaluz, S., A. F. Lòpez-Millàn, M. L. Peleato, J. Abadìa and A. Abadìa 2001. Phosphoenol pyruvate carboxylase: A key enzyme in irondeficient sugar beet roots. Plant Soil 60-66.

Aslam, M. and R. L. Travis. 2001. Diurnal Fluctuations of Nitrate Uptake and In vivo nitrate reductase activity in pima and acala cotton. Crop Sci. 41:372378.

Bialczyk, J. and L. Lechowski 1992. Absorption of $\mathrm{HCO}_{3}{ }^{-}$by roots and its effect on carbon metabolism of tomato. J. Plant Nutr. 15:293-312.

Bienfait, H. F., H. J. Lubberding, P. Heutink, L. Lindner, V. Visser, P. Kaptein and K. Dijkstra. 1989. Rhizosphere acidification by iron deficient bean plants: the role of trace amounts of divalent metal ions. A study on roots of intact plants with the use of ${ }^{11} \mathrm{C}$-and ${ }^{31} \mathrm{P}-\mathrm{NMR}$. Plant Physiol. 90:359-364.

Bienfait, H. F. 1996. Is there a metabolic link between $\mathrm{H}^{+}$excretion and ferric reduction by roots of $\mathrm{Fe}$-deficient plants - A viewpoint. J. Plant Nutr. 19:1211-1222.

Cesco, S., M. Nikolic, V. Römheld, Z. Varanini and R. Pinton 2001. Uptake of $59 \mathrm{Fe}$ from soluble $59 \mathrm{Fe}$-humate complexes by cucumber and barley plants. Plant Soil: 1-8.

Espen, L., F. F. Nocito and M. Cocucci. 2001. Abstract in the $6^{\text {th }}$ International Symposium on inorganic nitrogen 
assimilation, July 8-12, Reims Champagne France.

Davies, D. D. 1986. The fine control of cytosolic $\mathrm{pH}$. Physiol. Plant. 67:702-776.

Landsberg, E. C. 1981. Organic acid synthesis and release of hydrogen ions in response to $\mathrm{Fe}$ deficiency stress of mono and dicotyledonous plant species. J. Plant Nutr. 3:579591.

Landsberg, E. C. 1986. Function of rhizodermal transfer cells in Fe stress response mechanism of Capsicum annum L. Plant Physiol. 82:511-517.

Lòpez-Millàn, A. F., F. Morales, A. Andaluz, Y. Gogocena and A. Abadìa. 2000. Protective mechanisms in roots of iron deficient sugar beet: changes in carbon assimilation and oxygen use. Plant Physiol. 124:873884.

Miller, G. W., A. Shigematsu, G. W. Welkie, N. Motoji and M. Szlek. 1990. Potassium Effect on iron stress in tomato II. The effects on $\operatorname{root} \mathrm{CO}_{2}$ fixation and organic acid formation. J. Plant Nutr. 13:1355-1370.

Pich, A., G. Scholz and U. W. Stephan 1994. Iron-dependent changes of heavy metals, nicotianamine and citrate in different plant organs and in the xylem exudate of two tomato genotypes. Plant Soil 165:189-196.

Pich, A., G. Scholz and U. W. Stephan 1995. Iron-dependent changes of heavy metals, nicotianamine and citrate in different plant organs and in the xylem exudate of two tomato genotypes. In: J. Abadìa (Ed.) pp. 5158. Iron nutrition in soils and plants. Kluver Academic Publishers, Dordrecth, The Netherlands.
Rabotti, G., P. De Nisi and G. Zocchi 1995. Metabolic implications in the biochemical responses to iron deficiency in cucumber (Cucumis sativus L.) roots. Plant Physiol. 107:1195-1199.

Ritambhare, G. Kumar, S. Kavita, R. S. Dubey. 2000. Salinity induced behavioural changes in malate dehydrogenase and glutamate dehydrogenase activities in rice seedlings of differing salt tolerance. Plant Sci. 156:23-34.

Römheld, V. 1987. Different strategies for iron acquisition in higher plants. Plant Physiol. 70:231-234.

Takagi, S., K. Nomato and T. Takemoto. 1984. Physiological aspect of mugineic acid, a possibile phytosiderophore of graminaceous plants. J. Plant Nutr. 7:469-477.

Thoiron, N., Pascal and J. F. Briat 1997. Impact of iron deficiency and iron resupply during the early stages of vegetative development in maize (Zea mays L.). Plant Cell Environ. 20:1051-1060.

Singal H. R. and R. Sing. 1986. Purification and properties of phosphoenolpyruvate carboxylase from immature pods of chickpea (Cicer arietinum L.). Plant Physiol. 80:369-373.

Sweeley, C. C., R. Bentley, M. Makita and W. E. Welles. 1963. Gas-Liquid Partition of trimethylsilyl derivates of sugar and related substances. J. Amer. Chem. Soc. 85:2497-2507.

Tiffin, L. O. 1966. Iron traslocation II. Citrate/iron ratios in plant stem exudates. Plant Physiol. 41:515-518. 